\title{
Preliminary Mapping of Posdaya Performance as Family Empowerment Program
}

\author{
Pudji Muljono ${ }^{1}$ \\ ${ }^{1}$ Faculty of Human Ecology, Bogor Agricultural University, Indonesia \\ Correspondence: Pudji Muljono, Kampus IPB Darmaga, Bogor, Indonesia. E-mail: pudji1962@yahoo.co.id; \\ pudjimuljono@gmail.com
}

Received: August 18, 2014

Accepted: September 9, 2014 Online Published: November 4, 2014

doi:10.5539/jsd.v7n6p18

URL: http://dx.doi.org/10.5539/jsd.v7n6p18

\begin{abstract}
Posdaya is a model of family empowerment to revive the mutual cooperation culture to build human resources through active participation in the family. Posdaya performance can be assessed from several aspects, including aspects of secretarial, partnerships, education, economic, health and environmental aspects. Although Posdaya has grown quite well, but so far there has been no attempt to map Posdaya performance in Indonesia. The objectives of the study were to assess the performance of Posdaya in term of its secretarial, partnerships, education, economics, health, and the environment aspects. Based on the results of the study note that Posdaya is lack of its performance in partnership, economy and environment. Whereas for the growth status of Posdaya, they were classified into five category of Posdaya, namely potential Posdaya category, dinamic Posdaya category, productive Posdaya category, creative Posdaya category, and innovative Posdaya category. The results showed that of the 50 Posdaya studied, it turns out 54\% including productive Posdaya category, $30 \%$ are categorized as creative Posdaya category, and $16 \%$ are dynamic Posdaya category. There is no Posdaya with potential and innovative category. To improve the performance of Posdaya, is necessary to increase partnerships in the areas of program development, economic and environmental.
\end{abstract}

Keywords: empowerment, family, mapping, performance, Posdaya

\section{Introduction}

Pos Pemberdayaan Keluarga (Family empowerment post - which was shortened into Posdaya) is a model of family empowerment to revive the mutual cooperation culture to build human resources through active participation in the family. Posdaya was created as a forum for advocacy, communication, information, education to strengthen the coordination of activities of family functions. The target activities are implementing joint effort so that every family has the ability to perform eight functions of families, namely the development of a religious function or believe in God, the function of culture, the function of protection, the function of family planning and health, educational function, the function of economic and entrepreneurship, and environmental function (Muljono, Bachtiar, \& Sudarmo, 2012).

The Posdaya is an informal community communication forum that strives to empower all members of the community to improve their capacity to become actively involved in utilizing in an integrated manner all resources, both public and private, available to improve the lives of all individuals in community. The Posdaya is an approach to development which recognizes and promotes the notion that development is multifaceted and is greater then the sum of its individual parts. In other words it is more than discrete inputs by various sectors, be they health, education, cooperatives and the like. Rather it is through the synergies, the permutations and combinations of the various inputs which bring about higher levels of achievement than would be accomplished by any single input on its own (Suyono \& Parsons, 2010). In essence the overriding objective of Posdaya is to enhance family and community welfare and thus poverty alleviation (Damandiri Foundation and National Family Planning Coordinating Board, 2010).

According to Damandiri Foundation (2010) Posdaya advocates for the empowerment and active participation of all members in the family to strive for betterment. The Posdaya model combines and converges the MDGs, the eight functions of the families, and even the HDI into a single compact and streamlined concept for social development with the family as focus. Furthermore the Posdaya is a model for empowering all families and all within families, and nurtures harmony within the family and among families. Suyono and Haryanto (2009) stated 
that in order to carry out the expansion of the scope and development Posdaya with various activities carried out in stages, according to the three-dimensional phasing strategy is outreach, coaching, as well as the institutionalization and civilizing.

The number Posdaya in Indonesia at the moment is increasing. Since it was first established in the Village District Girimulya Cibungbulang, Bogor regency in 2007, it has now grown in number to 30,000 Posdaya in Indonesia (Damandiri Foundation, 2014). To outsiders as the driving the Posdaya growth, will also be very useful in taking appropriate steps to coaching Posdaya growth. Therefore, it is necessary to study performance mapping in order to be classified Posdaya development group designed the program so it can be relevant to each group of these developments in the context of community empowerment.

\section{Performance of Posdaya}

Posdaya as a model of community empowerment in Indonesia has been implemented since 2007. This program has been established as part of community development program planned by Bogor Agricultural University for the empowerment of communities living around the campus. This present study was carried out to evaluate the implementation of Posdaya development at a village around the campus, Cikarawang village, particularly to evaluate the socialization of healthy environment campaign, economic development and extension for waste management. The site selection for the study was based on purposive consideration, as the Cikarawang village has never experienced to enjoy Posdaya Program. The result of the study showed that the community leaders and the cadres of Posdaya were aware about the existance of Posdaya as well as its functions and importance for the community empowerment. Based on the results of studies conducted by the community leaders and the cadres Posdaya can be seen that public knowledge about Posdaya relatively well and they have to understand what and how about Posdaya. But the general public has not been fully supportive because the concrete realization in the form of programs and impact developed by Posdaya not be realized in practice (Muljono, 2013a).

The goal of the family empowerment program is to support the family in achieving their goals. This is accomplished through co-contruction of a service plan that addresses the family's needs in an efficient and coherent manner-emphasizing family strengths and competencies and supporting family self-sufficiency (Cleek, Wofsy, Boyd-Franklin, Mundy, \& Howell, 2012). According to Muljono (2013b) based on the performance of a sample Posdaya studies generally have not reached the optimum score for each of the variable measured. Posdaya generally low performance on aspects of partnership, economic and environmental. While the secretariat, education and health aspects; the Posdaya performance is generally quite good. Muljono (2013c) stated that based on the results of studies conducted by the community leaders and the cadres Posdaya can be seen that public knowledge about Posdaya relatively well and they have to understand what and how about Posdaya. But the general public has not been fully supportive because the concrete realization in the form of programs and impact developed by Posdaya not be realized in practice.

The Green-Posdaya programe has been accomplished to improve the quality of community empowerment, especially in the fields of economics, education, health and the environment. The programe is implemented in five villages in the District Klapanunggal, Bogor Regency; whose synergy between professional course work of Bogor Agricultural University student partnership programe through CSR activities of PT. Holcim. In the first year has been realized several achievements that are still pioneering activities and mentoring beginning, namely the development of Green-Posdaya, improved management of early childhood education, and strengthening microfinance institutions. It is expected that the activities of the next period, gradually achieved healthier living conditions and welfare of local communities (Muljono \& Saharuddin, 2013).

The results showed that the characteristics of the cadre Posdaya positively associated with communication activities including non-formal education, the experience of being a cadre, income level, motivation, media ownership, group dynamics and the role of companion that support the Posdaya activities (Pamungkas, 2013). Research conducted in the city of Bekasi shows that the three exogenous latent variables, namely leadership, governance management, and governance ethic; able to improve the quality of well-being of poor families through the process of empowerment effectiveness. Empowerment process is implemented in the form of Posdaya (Suwito, 2014).

Meanwhile Saleh, Rokhani \& Bahtiar (2014) stated that the development of social capital and entrepreneurial facing various problems of which the condition of human resources, planned programs, and mentoring. They suggest the presence of approaches and better communication to the stakeholders in the location of Posdaya. Furthermore, research conducted by Sadono, Saharuddin \& Yusalina (2014) shows that mentoring has enough Posdaya able to improve the board's ability to manage and promote Posdaya. Analysis of customer satisfaction 
index (CSI) shows the pattern board Posdaya satisfied with the assistance that is done, while the member is quite satisfied.

\section{Methodology}

\subsection{Posdaya Sample}

The study was conducted on 50 units of Posdaya spread over 3 locations, namely Bogor City, Bogor District, and Cianjur District, at West Java Province, Indonesia. Selection of Posdaya will be purposively sampled, due to the number and level of development of Posdaya. Posdaya in each location is different, so it is expected to obtain Posdaya diverse conditions. By considering the distribution of Posdaya that has evolved in the study site, the total amount of sample of Posdaya are 16 units of Posdaya located in Bogor District, 30 units of Posdaya in Bogor City and 4 units of Posdaya in Cianjur District.

\subsection{Data Collection}

Referring to the theories and constructs that underlie the formation, development and performance associated with Posdaya as a forum for advocacy, communication and community empowerment; subsequently developed the instruments or questionnaire to measure the development of Posdaya. Based on the theories that were examined, and then set the dimensions (aspects) and indicators (sub-aspects) that affect the overall performance of Posdaya as family empowerment model. Performance of Posdaya examined in this study include various aspects: secretarial, partnerships, education, economic, health and environmental aspects. Results obtained from the performance of Posdaya accumulated total score for each aspect of performance of Posdaya assessed, namely secretarial aspects, aspects of partnerships, educational aspects, economic aspects, health aspects, and environmental aspects. Total scores ranged from Posdaya performance score of 0 to 166.

The initial instrument design of the performance evaluation of Posdaya further tested to stakeholders and activists of Posdaya in targeted research areas. Instrument for testing the formulation consists of six main aspects i.e. aspects of secretariat, partnerships, education, economy, health and aspects of environment. Analysis of the instrument of Posdaya development measurement are conducted by test validity and reliability. Reliability tests indicated that the instrument of Posdaya performance evaluation with score $\alpha=0.845$.

Prior to data collection activities, conducted training of enumerators so that the data collection process takes place smoothly. In order to expedite the process of data collection, coordination with officials and cadres Posdaya which will be the object of study in each area of observation. The research data were collected by questionnaire, in-depth interview and Focus Group Discussion (FGD). Respondents and informants of this research come from elected officials Posdaya. Indepth interviews were conducted on the 300 key figures associated with the chairman of Posdaya community empowerment, health coordinator Posdaya, economics coordinator, field coordinator of environmental, education coordinator, and head of the village.

\subsection{Data Analysis Techniques}

Scoring techniques in determining the performance and Posdaya categorization refers to the classification as described below. Total weight of Posdaya performance score is between 0-100 which is the accumulation of weighted scores of the performance aspects of secretarial, partnerships, education, economics, health and environmental fields. Posdaya performance category is divided into five categories, with the scoring system and its description as follows.

a. Score $0-\leq 20=$ Potential Posdaya category, this is Posdaya that has potential to carry out activities of empowerment on four aspects/areas activities of Posdaya.

b. Score $21-\leq 40=$ Dynamic Posdaya category, this is Posdaya that has capable of implementing Posdaya empowerment programs in four areas activities.

c. Score $41-\leq 60=$ Productive Posdaya category, this is Posdaya that has capable of producing a superior product from one of the areas of Posdaya activity.

d. Score $61-\leq 80=$ Creative Posdaya category, this is Posdaya that able to be creative in producing superior products from one or more fields of Posdaya activity.

e. Score $81-\leq 100=$ Innovative Posdaya category, this is Posdaya that capable innovate in producing a superior product from one or more fields of Posdaya activity.

Data obtained from the study, further processed with the descriptive statistical analysis techniques in the form of categorization, tabulation and frequency. In addition, the field strength analysis to map the strengths, weaknesses, opportunities and challenges facing Posdaya as a model of community empowerment. 


\section{Results}

Assessment of Posdaya developments done in order to improve the quality of community development programs, at least in areas where the Posdaya has been formed. Consideration of fixing the sample Posdaya selected as the object of observation on mapping the distribution of performance based on the distribution of the number and level of development in the three regions Posdaya. Distribution of the number of samples Posdaya mapping studies Posdaya performance presented in Table 1.

Table 1. Number of Samples Posdaya appropriate Regional Distribution of Observations

\begin{tabular}{|c|c|c|c|}
\hline Nu. & District/City & Subdistrict & Total Posdaya Samples \\
\hline \multirow[t]{5}{*}{1} & Bogor District & Ciampea & 3 \\
\hline & & Cibungbulang & 2 \\
\hline & & Cigombong & 16 \\
\hline & & Dramaga & 9 \\
\hline & & Klapanunggal & 1 \\
\hline \multirow[t]{6}{*}{2} & Bogor City & West Bogor & 10 \\
\hline & & South Bogor & 5 \\
\hline & & Centre Bogor & 6 \\
\hline & & East Bogor & 2 \\
\hline & & North Bogor & 3 \\
\hline & & Tanah Sareal & 4 \\
\hline \multirow[t]{2}{*}{3} & Cianjur District & Cilaku & 3 \\
\hline & & Cugenang & 1 \\
\hline & & & 50 \\
\hline
\end{tabular}

Performance of Posdaya examined in this study include various aspects: secretarial, partnerships, education, economic, health and environmental aspects. Mapping results obtained from the performance Posdaya accumulated total score for each aspect of performance Posdaya assessed, namely secretarial aspects, aspects of partnerships, educational aspects, economic aspects, health aspects, and environmental aspects. Total scores ranged from Posdaya performance score of 0 to 166. The scores of Posdaya performance for every aspect subsequently converted to weighted scores, bringing the total amount to the maximum weighted performance score 100.00. Completed maximum score for each aspect can be seen in Table 2.

Table 2. The description of Posdaya performance in accordance with aspects

\begin{tabular}{llccc}
\hline & \multicolumn{1}{c}{ Aspects are assessed } & Total Score & Weighted Score \\
\hline 1. & Secretarial & 45 & 27,11 \\
2. & Partnership & 39 & 23,49 \\
3. & Education & 17 & 10,24 \\
4. & Economic & 18 & 10,84 \\
5. & Health & 35 & 21,08 \\
6. & Environmental & 12 & 7,23 \\
\hline \multicolumn{2}{r}{} & Total & $\mathbf{1 6 6}$ & $\mathbf{1 0 0 . 0 0}$ \\
\hline
\end{tabular}

\section{Secretarial Performance}

Performance of Posdaya for secretarial aspect consists of 12 items that are Posdaya name, Posdaya management, work plan of Posdaya, family map, secretariat, relevant decree of Posdaya, regular meetings, meetings temporal, recording, reporting, books administration, and financing. Referring to the answers given by the board of Posdaya that serve as the research sample, it can be seen that the entire of Posdaya has a name Posdaya coordinator. Percentage indicates both the maximum percentage that the performance of the highest secretarial aspects, which amounted to $100 \%$. Meanwhile, the performance of the lowest secretarial aspect is the fulfillment of others in the secretariat (4\%) and independently finance (8\%). It can be said that the secretarial aspects, to the financing aspects Posdaya few activities that are categorized as independent. 


\section{Partnership Performance}

Performance of Posdaya for partnership aspect consists of 12 items that are cooperation with the government, cooperation with the private sector, cooperation with other Posdaya, cooperation with educational institutions, cooperation with financial institutions, cooperation with social institutions, cooperation with other institutions, in collaboration with the PNPM (Program Nasional Pemberdayaan Masyarakat), collaboration with other programs, cooperative extension number of Posdaya, became the OST (observation study tour), and a builder Posdaya other. Referring to the answers given by the board of Posdaya that serve as the research sample, it can be seen that the performance aspect achieved the highest partnership for items cooperation with other institutions with less than a one year period $(90 \%)$ and also collaborations with other institutions with a validity period of less than year (90\%). Meanwhile, the performance aspect of the partnership is low or it never happened is cooperation with other relevant institutions with the help of working capital (0\%). In addition, the relatively low is that the shape of formal cooperation / binding (2\%) and related to institutional strengthening (2\%). It can be said that the partnership aspect, working capital assistance for Posdaya, formal cooperation / binding, and institutional strengthening Posdaya still relatively limited.

\section{Education Performance}

Performance of Posdaya for educational aspect consists of 7 items that are early childhood programs, community libraries, Kompudaya (computer programs for Posdaya), assemblies recitation, the number of students Packet A / B / C more than 10 people, literacy, and other programs. Referring to the answers given by the board of Posdaya that serve as the research sample, it can be seen that the performance aspect of higher education achievable for most items taklim assembly activities / lectures (96\%). Meanwhile, the performance of the lowest educational aspect is the initiation of a new program or any other form other than items 1 to 6 , ie, with pesentase $8 \%$. It can be said that in the aspect of education, more primary performance indicated by the percentage of early childhood activities in general performance above $70 \%$.

\section{Economic Performance}

Performance of Posdaya to the economic aspect consists of 18 items that are gathering program, saving Posdaya / Savings and Loans Unit, incorporated cooperatives, home industry, training / internship / economic development, marketing, processing, financing / credit, partnership, group, groups of women farmers, other activities, $50 \%$ of households are involved in economic activities, poor members is less than $30 \%$, capital raised more than USD 5 million, the initial capital of less than Rp 1 million, has a turnover of more than USD 10 million, and all the members have got benefits. Referring to the answers given by the board Posdaya that serve as the research sample, it can be seen that the economic aspects of the performance of the highest achievable for the home industry activity items (76\%). Meanwhile, the performance of the lowest economic aspects are incorporated cooperative program and the initiation of other activities in addition to the items 1 to 18 , ie, with pesentase $10 \%$. It can be said that the performance of Posdaya in economic aspects, the main performance more shown by the activities of home industry by utilizing local resources and potentials available in each area or community.

\section{Health Performance}

Performance of Posdaya for the health aspect consists of 7 items that are Integrated Health Centre (IHC, Posyandu) program, Posbindu Elderly, Bina Keluarga Balita (Family Coaching Toddlers), Bina Keluarga Remaja (Teens Family Development), Bina Keluarga Dewasa (Adult Family Development), Group Bina Keluarga Lansia (Elderly Family Development), and group other. Referring to the answers given by the board Posdaya that serve as the research sample, it can be seen that the performance of the health aspects of the highest achieved for items that routine IHC activities monthly, supplementary feeding (PMT, Program Makanan Tambahan), collaboration with health centers, in cooperation with midwives, health records toddler, and toddler nutrition notes. The entire item for performing IHC activities is $98 \%$. Meanwhile, the performance of the lowest health aspect is a program of activities with other groups, which in addition to items 3 to 6 , ie, with attainment percentage $8 \%$. It can be said that on health aspect, key performance Posdaya more activity shown by IHC with the performance of activity is generally more than $70 \%$ for the entire Posdaya observed.

\section{Environmental Performance}

Performance of Posdaya for the environmental aspect consists of 6 items ie household waste handling activities, activities of Biopori, Communal Activity Nursery, Gardens Nutrition, Tourism of Posdaya and other activities. Referring to the answers given by the board of Posdaya that serve as the research sample, it can be seen that the environmental aspects of the performance of the highest achieved for the IHC activity items of household waste 
handling activity and nutritious garden. Items such activities each performing $56 \%$ and $54 \%$. Meanwhile, the Posdaya performance of the lowest environmental aspect is Posdaya tour program, with percentage $8 \%$. It can be said that the environmental aspects, the main performance of Posdaya more activity shown by IHC with the performance of activity is generally more than $70 \%$ for the entire of Posdaya observed.

Referring to the results of test instruments or questionnaire that have been done, then we performed the categorization class of Posdaya growth based on performance achievement scores obtained. For 50 units of Posdaya that become the object of study, the category of Posdaya performance can be classified as presented in Table 3 .

Table 3. Posdaya categories according to the performance scores

\begin{tabular}{clccc}
\hline Nu. & Category of Posdaya & Score & Total of Posdaya (unit) & Percentage (\%) \\
\hline 1. & Potential category & $0-\leq 20$ & 0 & 0.00 \\
2. & Dinamic category & $21-\leq 40$ & 8 & 16.00 \\
3. & Productive category & $41-\leq 60$ & 27 & 54.00 \\
4. & Creative category & $61-\leq 80$ & 15 & 30.00 \\
5. & Innovative category & $81-\leq 100$ & 0 & 0.00 \\
\hline & Total & 50 & 100.00 \\
\hline
\end{tabular}

The order of performance of the weighted total score of 50 Posdaya observed, ranging from the lowest score (29.52) to the highest score (78.31) are listed in Table 4. There are $16.00 \%$ units of Posdaya performance belong to the category of dynamic Posdaya category, $54.00 \%$ units of Posdaya belong to the category of productive Posdaya category, and 30\% units of Posdaya classified the creative Posdaya category. No performance of Posdaya category which including the potential Posdaya category and innovative Posdaya category.

Table 4. Grouping the Posdaya based on their performance score and category

\begin{tabular}{|c|c|c|c|c|c|c|}
\hline $\mathrm{Nu}$ & Score & Posdaya Name & Village & Sub-district & District/City & Posdaya Category \\
\hline 1. & 29.52 & Berdikari & Cimanggu 1 & Cibungbulang & Bogor district & Dynamic \\
\hline 2. & 30.72 & Melati & Curug & Bogor Barat & Bogor city & Dynamic \\
\hline 3. & 35.54 & Sauyunan & Sukadamai & Tanah Sareal & Bogor city & Dynamic \\
\hline 4. & 36.75 & Sejahtera & Tanah Baru & Bogor Utara & Bogor city & Dynamic \\
\hline 5. & 37.35 & Tunas Harapan & Sukawening & Dramaga & Bogor district & Dynamic \\
\hline 6. & 37.95 & Sirna Galih & Sirna Galih & Cilaku & Cianjur district & Dynamic \\
\hline 7. & 39.16 & Tunas Mekar & Mekarwangi & Tanah Sareal & Bogor city & Dynamic \\
\hline 8. & 39.76 & Maju Jaya & Gunung Batu & Bogor Barat & Bogor city & Dynamic \\
\hline 9. & 41.57 & Igor Jaya & Pasir Jaya & Cigombong & Bogor district & Productive \\
\hline 10. & 41.57 & Subur Makmur & Cihideung Ilir & Ciampea & Bogor district & Productive \\
\hline 11. & 42.77 & Mandiri & Cibuluh & Bogor Utara & Bogor city & Productive \\
\hline 12. & 43.37 & Kamboja & Batu Tulis & Bogor Selatan & Bogor city & Productive \\
\hline 13. & 44.58 & Panaragan Kidul Asri & Panaragan & Bogor Tengah & Bogor city & Productive \\
\hline 14. & 44.58 & Harmonis & Baranangsiang & Bogor Timur & Bogor city & Productive \\
\hline 15. & 45.78 & La Tahzan & Sempur & Bogor Tengah & Bogor city & Productive \\
\hline 16. & 46.99 & Kenanga & Tegallega & Bogor Tengah & Bogor city & Productive \\
\hline 17. & 46.99 & Bina Sejahtera & Situ Udik & Cibungbulang & Bogor district & Productive \\
\hline 18. & 49.40 & Sejahtera Mandiri & Sukasari & Bogor Timur & Bogor city & Productive \\
\hline 19. & 49.40 & Sunan Gunung Jati & Kertamaya & Bogor Selatan & Bogor city & Productive \\
\hline 20. & 49.40 & Nusa Indah & Bantarjati & Klapanunggal & Bogor district & Productive \\
\hline 21. & 50.00 & Anggrek & Mulyaharja & Bogor Selatan & Bogor city & Productive \\
\hline 22. & 50.00 & An Nur & Galudra & Cugenang & Cianjur district & Productive \\
\hline 23. & 51.20 & Harapan Maju & Sukadamai & Dramaga & Bogor district & Productive \\
\hline 24. & 52.41 & Kujang & Babakan Pasar & Bogor Tengah & Bogor city & Productive \\
\hline 25. & 52.41 & Kencana Indah & Kencana & Tanah Sareal & Bogor city & Productive \\
\hline 26. & 53.61 & Permata & Balumbang Jaya & Bogor Barat & Bogor city & Productive \\
\hline 27. & 54.82 & Fajar Harapan & Purwasari & Dramaga & Bogor district & Productive \\
\hline 28. & 54.82 & Bersatu & Bojongkerta & Bogor Selatan & Bogor city & Productive \\
\hline
\end{tabular}




\begin{tabular}{|c|c|c|c|c|c|c|}
\hline $\mathrm{Nu}$ & Score & Posdaya Name & Village & Sub-district & District/City & Posdaya Category \\
\hline 29. & 54.82 & Sabilulungan & Neglasari & Dramaga & Bogor district & Productive \\
\hline 30. & 55.42 & Menteng Berkarya & Menteng & Bogor Barat & Bogor city & Productive \\
\hline 31. & 57.23 & Baraya & Dramaga & Dramaga & Bogor district & Productive \\
\hline 32. & 57.83 & Semai Mulia & Cibanteng & Ciampea & Bogor district & Productive \\
\hline 33. & 59.04 & Sari Kenanga & Ciwaringin & Bogor Tengah & Bogor city & Productive \\
\hline 34. & 59.04 & Melati Bondes & Kebon Pedes & Tanah Sareal & Bogor city & Productive \\
\hline 35. & 59.64 & Bersama & Petir & Dramaga & Bogor district & Productive \\
\hline 36. & 60.24 & As Salam & Sirnagalih & Cilaku & Cianjur district & Creative \\
\hline 37. & 60.84 & Wijaya Kusuma & Kebon Kelapa & Bogor Tengah & Bogor city & Creative \\
\hline 38. & 61.45 & Mandiri Terpadu & Cikarawang & Dramaga & Bogor district & Creative \\
\hline 39. & 62.05 & Mekarsari & Sinarsari & Dramaga & Bogor district & Creative \\
\hline 40. & 63.25 & Melati Mandiri & Ciparigi & Bogor Utara & Bogor city & Creative \\
\hline 41. & 65.66 & Mandiri & Sindangbarang & Bogor Barat & Bogor city & Creative \\
\hline 42. & 66.27 & Sauyunan & Ciherang & Dramaga & Bogor district & Creative \\
\hline 43. & 66.27 & Pancagalih & Loji & Bogor Barat & Bogor city & Creative \\
\hline 44. & 66.27 & Soka & Cikaret & Bogor Selatan & Bogor city & Creative \\
\hline 45. & 67.47 & Sejahtera & Bubulak & Bogor Barat & Bogor city & Creative \\
\hline 46. & 69.28 & Bina Sejahtera & Pasirmulya & Bogor Barat & Bogor city & Creative \\
\hline 47. & 69.88 & Pasir Sembung Indah & Sirnagalih & Cilaku & Cianjur district & Creative \\
\hline 48. & 69.88 & Eka Mandiri & Cihideung Udik & Ciampea & Bogor district & Creative \\
\hline 49. & 73.49 & Puspa Lestari & Pasirkuda & Bogor Barat & Bogor city & Creative \\
\hline 50. & 78.31 & Kenanga & Situgede & Bogor Barat & Bogor city & Creative \\
\hline
\end{tabular}

Referring to the results of compilation of Posdaya on six aspects of performance observed in this study, if the six aspects are correlated with each other it will be seen as presented in Table 5. Secretarial aspects of Posdaya correlated significantly with aspects of partnership of Posdaya at the level of 0.01 and was significantly correlated well with economic aspects at the 0.05 level. Aspects of the partnership of Posdaya turned out to correlate significantly with secretarial aspects, educational aspects and economic aspects of Posdaya at the 0.01 level. Aspects of education of Posdaya correlated significantly with partnership and economic aspects of the 0.01 level. Economic aspects of Posdaya correlated significantly with aspects of partnership and educational aspects at the level of 0.01 and was significantly correlated well with secretarial aspects of the 0.05 level, and then health aspects correlated with environmental aspects of Posdaya at the 0.05 level. According to Table 5, the Posdaya performance aspect of the partnership is in line with the performance aspect of the secretarial, education and economics. If the performance of Posdaya is good in aspects of the partnership, then the performance of Posdaya in aspect of secretariat, education and economics will be better. Meanwhile, the performance Posdaya on aspects of health and environmental aspects need better efforts to improve the Posdaya programs in these areas.

Table 5. The correlation between performance aspects of Posdaya

\begin{tabular}{lcccccc}
\hline \multicolumn{1}{c}{ Variable } & Secretarial & Partnership & Education & Economic & Health & Environmetal \\
\hline Secretarial & & $0.532 * *$ & 0.275 & $0.336^{*}$ & $-0,006$ & 0.056 \\
Partnership & $0.532 * *$ & & $0.485^{* *}$ & $0.413 * *$ & 0.239 & 0.020 \\
Education & 0.275 & $0.485^{* *}$ & & $0.373 * *$ & 0.265 & 0.012 \\
Economic & $0.336 *$ & $0.413 * *$ & $0.373 * *$ & & 0.172 & 0.212 \\
Health & -0.006 & 0.239 & 0.265 & 0.172 & & $0.354 *$ \\
Environmetal & 0.056 & 0.020 & 0.012 & 0.212 & $0.354 *$ & \\
\hline
\end{tabular}

Exp: $* *=$ Significant correlation at the level of 0.01 (2-tailed), Pearson Correlation, $N=50$

$*$ Significant correlation at the level of 0.05 (2-tailed), Pearson Correlation, $N=50$

\section{Discussion}

Based on analysis of the gains for the six aspects of Posdaya observed, it can be planned Posdaya development program for each aspect of the performance, the set refers to the type of activity the most is not done on every aspect of performance, as further described below. Posdaya development priority programs for secretarial aspects are creating partnerships chart of Posdaya, make a family map Posdaya, and writing work plan of 
Posdaya. Programme priorities for aspects of Posdaya development partnerships are increased formal cooperation (bind) with other parties, seek the assistance of working capital, and institutional strengthening Posdaya. Posdaya priority development programs for educational aspects are the development of community libraries (libraries) of Posdaya, promote the program kompudaya, and developing packet Program A/B/C at the local site.

The Posdaya development priority programs for the economic aspects are development of cooperatives are legal entities, promote an increase in turnover of, and the collection of working capital. Posdaya development priority programs for the health aspects are enhanced cooperation for the development of integrated health, promote the development of elderly Posbindu, and development of an adult family development program (Bina Keluarga Dewasa). The Posdaya development priority programs for the environmental aspects are development of tourism programs of Posdaya, seek relevant breeding programs, and development of biopori programs.

\section{Conclusion}

Based on the results of this study, it can be concluded that Posdaya performance now is lack of its partnership performance, economy performance and environment performance. Whereas for the growth status of Posdaya, they were classified into five classes of Posdaya, namely potential Posdaya category, dinamic Posdaya category, productive Posdaya category, creative Posdaya category, and innovative Posdaya category. The results showed that of the 50 units of Posdaya studied, it turns out 54\% including Posdaya productive category, 30\% are categorized as creative Posdaya category, and $16 \%$ are dynamic Posdaya category. To improve the performance of Posdaya, should be done in the field of Posdaya partnership program development, economic and environmental sector.

Advice can be given on the results of the development of measurement instruments of Posdaya are: (a) There needs to be further research to apply the measurement instruments that can be mapped performance of Posdaya growth in various areas and can be developed to suit the conditions and potential of Posdaya respectively; (b) should be developed any programs for Posdaya with weak performance, especially in the partnership, economic and environmental aspects.

\section{Acknowledgements}

Gratitude to the Ministry of Education and Culture of the Republic of Indonesia, which has funded this research. The Board of Posdaya around the region of Bogor and Cianjur, that have been willing to become respondents in this study.

\section{References}

Cleek, E. N., Wofsy, M., Boyd-Franklin, N., Mundy, B., \& Howell, T. J. (2012). The family empowerment program: an interdisciplinary approach to working with multi-stressed urban families. Family Process, 51(2), 207-217. http://dx.doi.org/10.1111/j.1545-5300.2012.01392.x

Damandiri Foundation and National Family Planning Coordinating Board. (2010). The village family empowerment post (Posdaya), invites international observers: MDGs at the grassroots. Yogyakarta, Indonesia.

Damandiri Foundation. (2010). MDGs and the eight functions of Indonesian families: Refreshing the paradigm for family development. Jakarta: Damandiri Foundation.

Damandiri Foundation. (2014). Final report of community empowerment program in Indonesia. Jakarta: Damandiri Foundation.

Muljono, P. (2010). The posdaya model for community empowerment. Journal of Community, Culture and Politics, 23(1), 9-16.

Muljono, P. (2011). The model of family empowerment program for community development in West Java, Indonesia. Journal of Agricultural Extension and Rural Development, 3(11), 193-201.

Muljono, P. (2013a). The role of posdaya in shaping community empowerment: Case study at Cikarawang village, Bogor, Indonesia. Asian Journal of Humanities and Social Studies, 1(5), 225-232.

Muljono, P. (2013b). Performance evaluation of posdaya as family empowerment model in Indonesia. Asian Journal of Humanities and Social Studies, 1(4), 173-178.

Muljono, P. (2013c). Replication of posdaya for community empowerment programe: case study at Situgede village, Bogor, Indonesia. Asian Journal of Humanities and Social Sciences, 1(3), 1-8.

Muljono, P., \& Saharuddin. (2013). Development of green-posdaya programe to improve the quality of 
community empowerment. Proceedings of the seminar on the research and community service (pp. 717-729). Bogor: Bogor Agricultural University.

Muljono, P., Bachtiar, Y., \& Sudarmo, M. (2012). 101 Ways to know posdaya: the model of community development in Indonesia. Saarbruken: LAP Lambert Academic Publishing.

Pamungkas, S. (2013). The relationship between the level of communication activity posdaya empowerment cadres in the city and district of Bogor (Unpublished master's thesis). Bogor Agricultural University, Bogor, Indonesia.

Sadono, D., Saharuddin, \& Yusalina. (2014). Customer satisfaction index for family empowerment program. Journal of Social Welfare, 1(1), 1-12. Retrieved from http://www.universitas-trilogi.ac.id/ journal/ ks.

Saleh, A., Rokhani, \& Bahtiar, R. (2014). Support external relations and entrepreneurship through social capital model againt posdaya in Bogor and Cianjur district. Journal of Social Welfare, 1(1), 25-38. Retrieved from http://www.universitas-trilogi.ac.id/journal/ks.

Suwito, S. (2014). The effectiveness of empowerment program. Journal of Social Welfare, 1(1), 13-24. Retrieved from http://www.universitas-trilogi.ac.id/journal/ks.

Suyono, H., \& Haryanto, R. (2009). Handbook of posdaya development. Jakarta: Balai Pustaka.

Suyono, H., \& Parsons, J. (2010). "Posdaya” a paradigm shift in people centered development. Jakarta: Damandiri Foundation.

\section{Copyrights}

Copyright for this article is retained by the author(s), with first publication rights granted to the journal.

This is an open-access article distributed under the terms and conditions of the Creative Commons Attribution license (http://creativecommons.org/licenses/by/3.0/). 